\title{
Morphological and Molecular Identification of Some Intestinal Helminths Infesting the Domestic Pigeon (Columba livia domestica) at Ismailia, Egypt
}

\author{
Nada A. Ibrahim, Ehssan A. Hassan*, Tarek I. Moawad and Mahi A. Ghobashy \\ Suez Canal University, Faculty of Science, Department of Zoology, Ismailia, Egypt
}

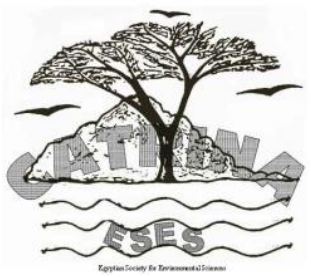

\begin{abstract}
The study identified helminths infecting the domestic pigeon, Columba livia domestica using conventional methods (Light and Environmental scanning electron microscopes) as well as the newly introduced molecular biology methods. 120 pigeons were purchased from Ismailia, Egypt during the period from December, 2015 to November, 2016. Light and Environmental scanning electron microscopes were used to study the general morphology and the surface features of the recovered parasites. The identification of the recovered helminths was confirmed using molecular biology techniques. Four helminths were recorded; one nematode (Ascaridia columbae) and three cestodes (Cotugnia polyacantha, Raillietina beveridgei and Raillietina echinobothrida). The total helminths prevalence was 58.3\%. Parasites DNA sequence data was used in Blast test, in order to confirm the identities of recovered cestodes. The phylogenetic tree of $C$. polyacantha picked only one sequence belong to Cotugnia sp. from India, in turn, this may be the first time for C. polyacantha $18 \mathrm{~S}$ rRNA to be submitted to GenBank from Egypt. Also, PCR reaction positively identified our nematode as A. columbae. Therefore, it is recommended to use molecular technique in helminths identification as the main methodology for correct identification especially in closely related species.
\end{abstract}

Keywords: Columba livia domestica, ESEM, Helminths, Molecular biology, Morphology.

\section{INTRODUCTION}

The poultry industry has been confronted with various parasitic diseases of economic significance (Anwar et al., 2000). Pigeons have shown high prevalence of gastrointestinal helminths and protozoan infections (Ghazi et al., 2002). Pigeons are cosmopolitan birds (Sari et al., 2008) and those of the order: Columbiformes can be found, virtually, in every town and city around the globe (Marques et al., 2007). Among which is the domestic pigeon Columba livia domestica that rose for food production (meat and eggs). Parasitism is gradually being accepted as one of the major selective forces affecting avian life histories. Birds can be parasitized by a wide variety of ecto and endoparasites (Marques et al., 2007 and Sivajothi and Reddy, 2014).

The common internal parasitic infections occur in poultry include cestodes and nematodes that cause considerable damage and great economic losses to the poultry industry. Furthermore, helminths can make the flock less resistant to diseases and exacerbate existing disease conditions (Katoch et al., 2012).

Nematodes are considered to be most important group of helminth parasites of poultry both in number of species and the degree of damage they cause; the main genera include Ascaridia, Heterakis, Syngamus and Capillaria (Matur and Dawam, 2010). Some species of Ascaridia have been found in pigeons (Foronda et al., 2004). A. columbae is a common parasite found in the small inte-stine of pigeons. Raillietina species are considered one from the most important cestodes of poultry. They are common in tropics, where the poor standard husba-ndry practices and climatic conditions are favorable for the development of the parasites (Tadelle and Ogle, 2001). Keeping in view the severity of the parasitic helminths, our research plan aims to identify the intestinal helminths infecting the domestic pigeon (Columba livia domestica) in Ismailia governorate using light and scanning electron microscopy coupled with molecular identification

\section{MATERIALS AND METHODS}

\section{The Birds collection:}

120 domestic pigeon (Columba livia domestica) were purchased from a birds market in Ismailia province, Egypt during the period from December, 2015 to November, 2016. They were immediately transported to the laboratory and were killed by anesthesia using overdose of chloroform.

\section{Helminths identification:}

Pigeons were dissected according to the method described by Al-Hussaini and Demian (1982) and the ileum was taken out separately in Petri-dish containing warm saline solution $(0.9 \%)\left(37^{\circ} \mathrm{C}\right)$. Dissected organ were carefully examined under Wild M3Z Continues Zoom Stereoscope for presence of parasites. Collected parasites from infected pigeons were washed several times in warm saline solution to remove mucous and other host debris and then sorted into nematodes and cestodes.

Specimens were preserved and cleared with Lactophenol. Glycerol jelly method used for nematodes specimens after Fleck and Moody (1993). The parasites were identified under binocular microscope light microscope according to Soulsby (1982) and Yamaguti (1961). The measurements of helminths were made with a calibrated ocular micrometer. Large nematode specimens were measured directly for their total length prior to mount. The parasites were examined and photographed by using Axiostar Plus (Carl Zeiss, Gottingen, Germany) microscope equipped with Canon (Pc 1200 power shoot 
A641) digital camera using Zoom Browser Ex software at the central lab of Zoology Department, Faculty of Science, Suez canal university, Ismailia.

\section{Environmental scanning electron microscopy (ESE- M)}

Samples were preserved in $70 \%$ ethanol; their morphological ultrastructure features were studied using Environmental Scanning Electron Microscope (Inspect S; FEI, Holland) at Electron Microscopy Unit of Theodor Bilharz Research Institute (TBRI) using standard method.

\section{Molecular identification}

Identification of the isolated parasites was confirmed by DNA barcoding technique. Parasites were kept frozen at $\left(-18^{\circ} \mathrm{C}\right)$ till the time of DNA extraction. Concentrations of genomic DNA $(n g / \mu l)$ and purity $(260 / 280$ $\mathrm{nm}$ ) were determined using Nanodrop (1000) spectro- photometer after calibration with sterilized double distilled water as a blank. Agrose gel electrophoresis was used to detect the quality of DNA. The genes $18 \mathrm{~S}$ rRNA and ITS2 for cestodes and mitochondrial genome ( $\mathrm{mt}$ ) for A. columbae were amplified with the universal primers described in table (1). PCR amplification was carried out in $\mathrm{T} 3$ thermocycler (Biometra) using the following thermal conditions: $5 \mathrm{~min}$ at $95^{\circ} \mathrm{C}$ of the initial denaturation step and $30 \mathrm{sec}$ at $95^{\circ} \mathrm{C}$ of the second denaturation step for both Ascaridia columbae and flat worms followed by annealing step $\left(50^{\circ} \mathrm{C}\right.$ for $30 \mathrm{sec}, A$. columbae; $55^{\circ} \mathrm{C}$ for $45 \mathrm{sec}$, flat worms), then the extension step was $72^{\circ} \mathrm{C}$ for $30 \mathrm{sec}$ at for A. columbae and $72^{\circ} \mathrm{C}$ for $45 \mathrm{sec}$, for flat worms. The reaction was terminated by a final extension step $\left(7 \mathrm{~min}\right.$ at $72^{\circ} \mathrm{C}$ and finally kept at $\left.4^{\circ} \mathrm{C}\right)$. Molecular analysis of the obtained DNA sequence data was carried using the software publically available on the web (https://blast.ncbi.nlm. nih. gov/Blast.cgi).

Table (1): The primers sequences used in 18S rRNA, ITS2 genes and mt genome amplification.

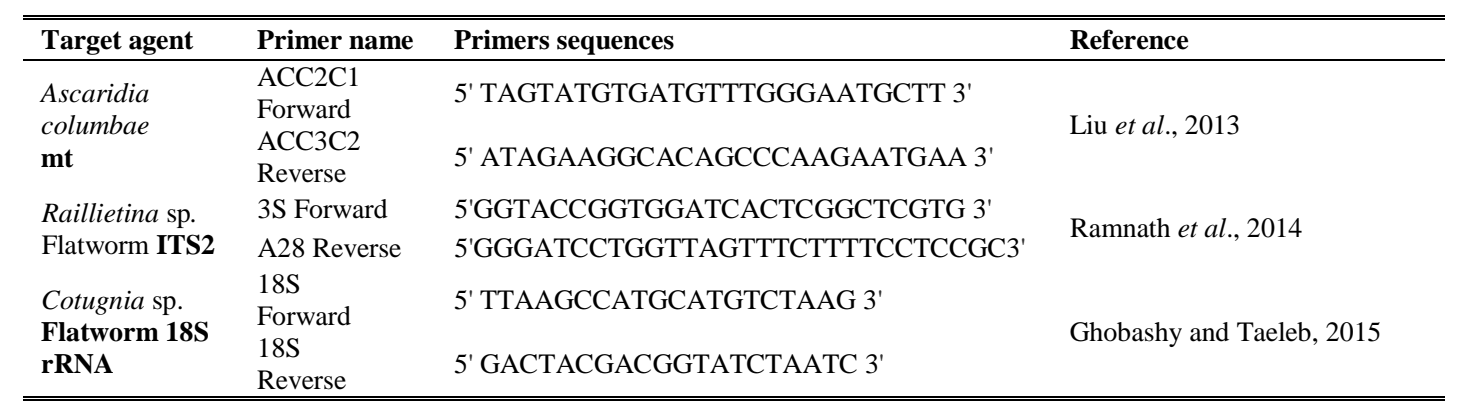

\section{RESULTS}

\section{Recovered helminths}

Four helminths species are recorded from the pigeon's ileum part. They are one nematode (Ascaridia columbae) and three cestodes (Cotugnia polyacantha, Raillietina beveridgei and Raillietina echinobothrida). The overall prevalence of infection was $58.3 \%$. A. columbae body was provided by transverse striations. There are 2 narrow lateral alae or flanges extending along the anterior half of the body. The mouth is surrounded by 3 globular, trilobed, equal seize lips with each lip has 2 cervical papillae. The oesophagus is club shaped without posterior bulb. Male measures 26-28 mm long and $0.73-1 \mathrm{~mm}$ wide. The oesophagus measures $1.8-2.3 \mathrm{~mm}$ long. The precloacal sucker is provided with strong chitinized wall and it measures $0.19-0.21 \mathrm{~mm}$ in diameter. The spicules are strong and equal or slightly subequal with 1.4-1.6 mm long. There are 13 pairs of caudal papillae. Female measures 37.9-40.3 mm long and 0.9$1.1 \mathrm{~mm}$ wide. The oesophagus measures 2.1-2.4 mm long. The tail is long, narrow and pointed. The vulva aperture is nearly posterior to the middle of the body (Figures 1 and 2). Scolex of $C$. polyacantha measures 0.3-0.4 X 0.2-0.3 mm diameter with four unarmed circ- ular suckers, each measures $0.09-0.1 \mathrm{~mm}$ in diameter. Large retractile and oval rostellum measures $0.1-0.2 \mathrm{~mm}$ in diameter. It armed with hooks that arranged in 2 rows. Behind these hooks, numerous very flat scaly spin shaped forming indentation at the base of rostellum. Mature segment contains two set of reproductive organs and measures $0.6-0.8 \times 2.5-2.8 \mathrm{~mm}$ with 2 genital pores. Genital pores located marginally at the middle of the segment sides one on each side. Gravid segment measures 1.2-2 X 4-5 mm; it filled with egg capsules, each with single egg. The testes are small in size, rounded in shape, 90 to 100 in numbers, lying in a single field, in posterior half of the proglottids (Figures 3 and 4).

Concerning Raillietina species, both $R$. beveridgei and $R$. echinobothrida have scolex $(0.4-0.7$ X $0.2-0.5$ $\mathrm{mm}$; 0.2-0.3 X 0.3-0.5 mm) with four armed circular suckers $(0.13-0.2 \mathrm{~mm} ; 0.1-0.3 \mathrm{~mm})$. They have large retractile and oval rostellum (0.1-0.3 mm;0.1-0.2 mm) armed with hooks that arranged in 2 rows. Mature segment (1.2-1.6 X 0.3-0.4 mm; 0.42-0.45 X 0.6-0.8 $\mathrm{mm})$ with unilateral, single genital pores. Gravid segment (0.3-0.5 X 2.3-2.6 mm; 0.3-0.5 X 0.4-0.7 mm) filled with egg capsules, each with more than one egg, respectively. The testes are small in size, rounded in shape 5-9 in numbers in $R$. beveridgei and 20-25 in $R$. 


\section{Ibrahim et al.}

echinobothrida (Fig. 5). Body proglottids of $R$. beveridgei have a smooth surface as they appear in the ESEM micrographs (Fig. 6) and are with longitudinal folds in R. echinobothrida (Fig. 7).

PCR amplifications and analysis of 18S rRNA and ITS2 genes for the cestode samples and mt genome for A. columbae

Nematode samples (A. columbae) are analyzed and they gave higher purity (standard: 1.82) and low concentration of DNA $93 \mathrm{ng} / \mu \mathrm{l}$ while the 3 samples of cestodes species ( $R$. beveridgei, $R$. echinobothrida, $C$. polyacantha) gave purity (1.8-1.79-1.82) and gave low concentration (75-102-88 $\mathrm{ng} / \mu \mathrm{l})$ respectively. The nematodes and cestodes specimens were identified according to the morphological criteria; as A. columbae for nematode and $C$. polyacantha, $R$. echinobothrida and $R$. beveridgei for cestodes, then they were molecular identified, $C$. polyacantha were identified based on 18S rRNA gene and the Raillietina species were identified based on ITS2 and A. columbae were also identified based on mt genome. The PCR product molecular size was $178 \mathrm{bp}$ for $A$. columbae, $800 \mathrm{bp}$ for C. polyacantha, $450 \mathrm{bp}$ for $R$. echinobothrida and 1000 bp for R. beveridgei (Fig. 8).
18S rRNA and ITS2 sequencing, editing and submission to GenBank

The three sequences of $C$. polyacantha, $R$. beveridgei and $R$. echinobothrida had been blasted on Genbank and the result for each one as following: $C$. polyacantha gave maximum identity $99 \%, 0.0 \mathrm{E}$ value and query cover of $100 \%$ with $C$. polyacantha (KR082007.1) from India. While $R$. beveridgei gave maximum identity $99 \%$, $0.0 \mathrm{E}$ values and query cover of $100 \%$ with $R$. beveridgei (AY382318.1) from Australia and $R$. echinobothrida gave maximum identity 99\%, $0.0 \mathrm{E}$ value and query cover of $100 \%$ with $R$. echinobothrida (JN797628.1) from India. Editing nucleotide sequences for 18S rRNA for $C$. polyacantha and ITS2 for 2 species of Raillietina in the current study are shown in table (2) with their accession number on GenBank.

\section{Phylogenetic analysis}

The phylogenetic tree $R$. beveridgei and R. echinobothrida using the obtained ITS2 DNA sequence data as well as the published sequences of related cestodes is shown in figure (9). C. polyacantha phylogenetic tree was constructed using our partial 18S rRNA sequence and the related sequences available on GenBank are shown in figure (10).

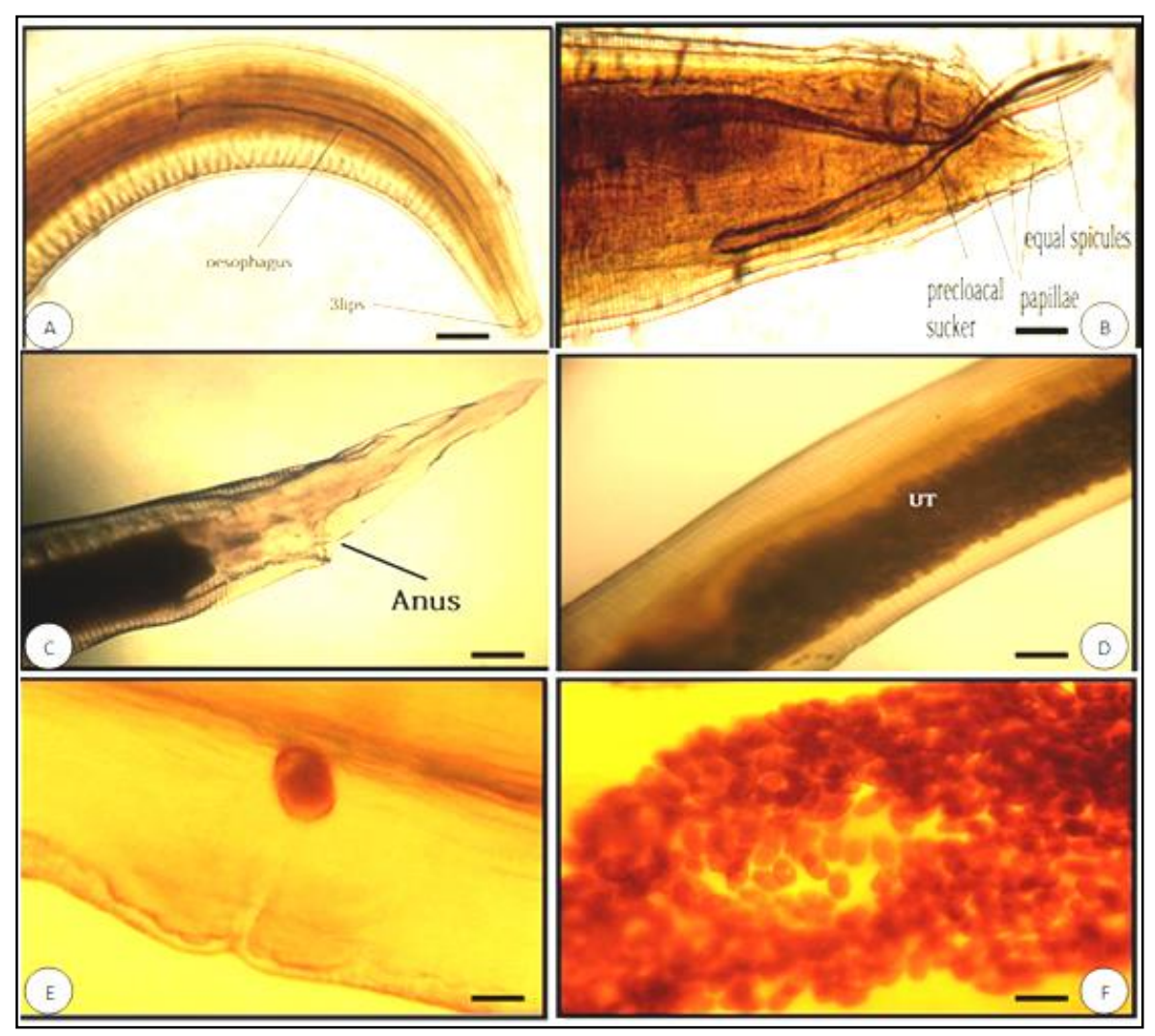

Figure (1):A. columbae (A) Anterior end, showing the club-shaped oesophagus and the three lips. Scale bar $=100 \mu \mathrm{m}$. (B) Posterior end of male showing 2 spicules, precloacal sucker and caudal papillae (Lactophenol). Scale bar $=100 \mu \mathrm{m}$. (C) Posterior end of female showing the anus and the pointed end. Scale bar $=100 \mu \mathrm{m}$. (D) The middle part of female showing uterus with eggs (Lactophenol). Scale bar $=100 \mu \mathrm{m}$. (E) The middle part of female showing the vulval opening (Lactophenol). Scale bar $=25 \mu \mathrm{m}$. (F) The middle part of female showing the oval-shaped, thick shelled eggs (Lactophenol). Scale bar $=25 \mu \mathrm{m}$. 


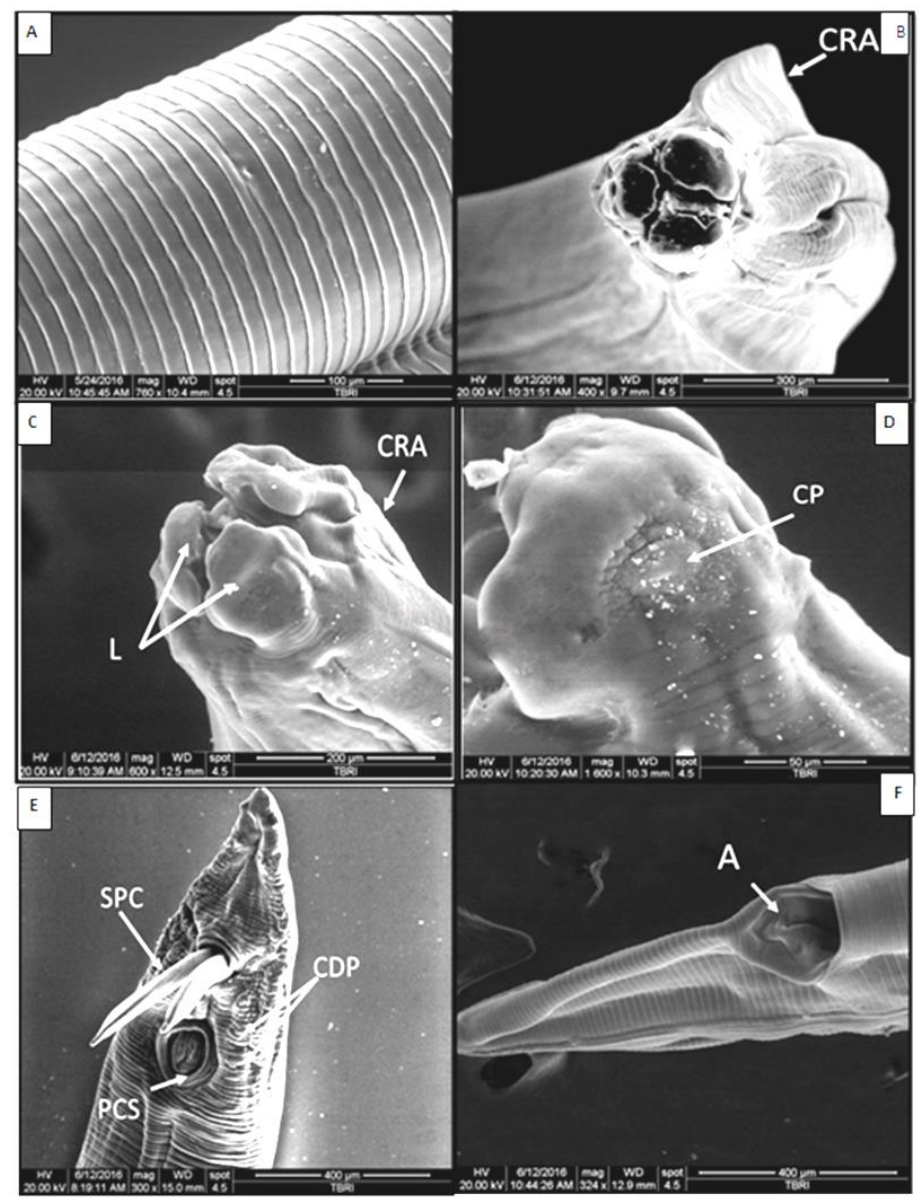

Figure (2): ESEM of A. columbae showing (A) cuticular surface of the body; (B) The narrow lateral cervical alae (CRA); (C) The anterior part showing mouth with 3 trilobed lips (L) and cervical alae (CRA); (D) The cervical papillae (CP) of one lip of the mouth; (E) The posterior end of male showing the pre-cloacal sucker (PCS), caudal papillae (CDP) and two spicules (SPC); (F) The posterior end of female showing the anus (A).

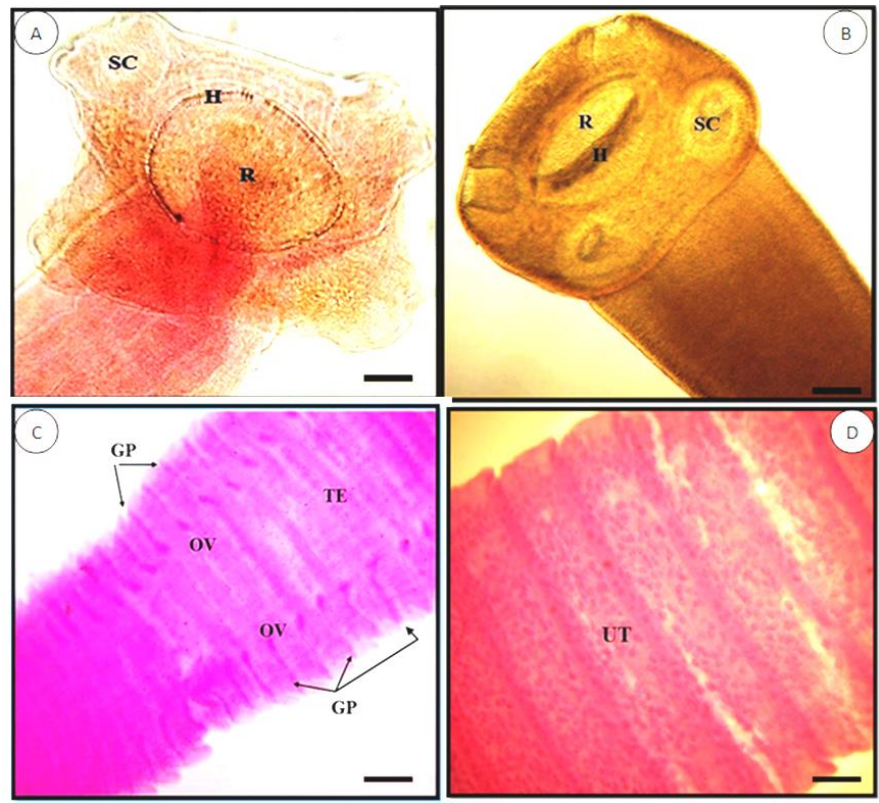

Figure (3): Whole amount of C. polyacantha; (A and B) the anterior part showing rostellum (R) with hooks (H) and 4 suckers (SC) (Acetic alum carmine), (Lactophenol). (C) Mature proglottids showing 2 ovaries (OV), several testes (TE) and genital pores (GP) on both sides of each proglottid (Acetic alum carmine). (D) Gravid proglottids showing eggs filling the uterus (Acetic alum carmine). Scale bar $=100 \mu \mathrm{m}$ for all photos. 


\section{Ibrahim et al.}

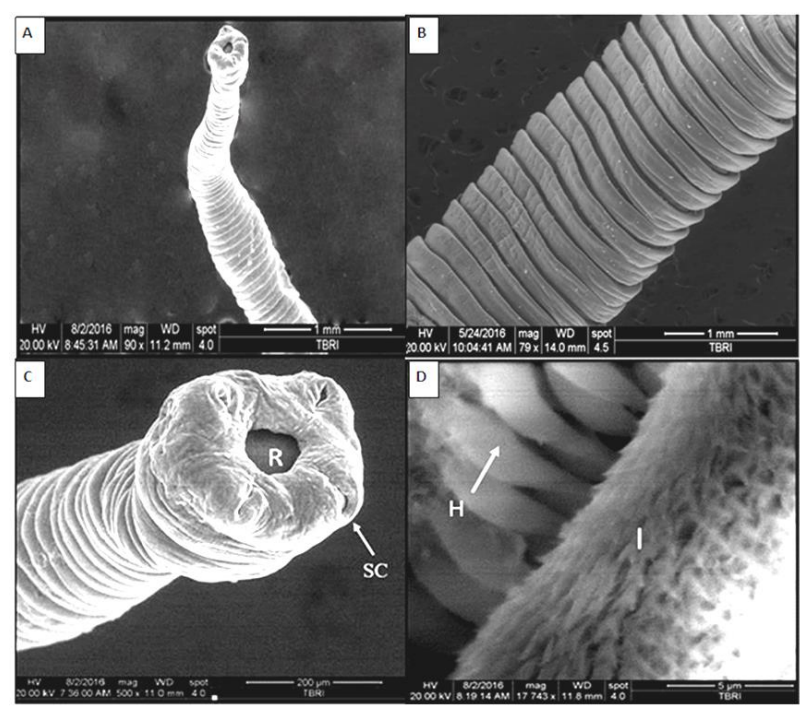

Figure (4): ESEM of $C$. polyacantha showing (A) scolex and strobila with numerous proglottids; (B) Body proglottids. (C) The anterior part showing rostellum (R) and 4 suckers (SC); (D) The anterior part showing hooks (H) and indentation (I).

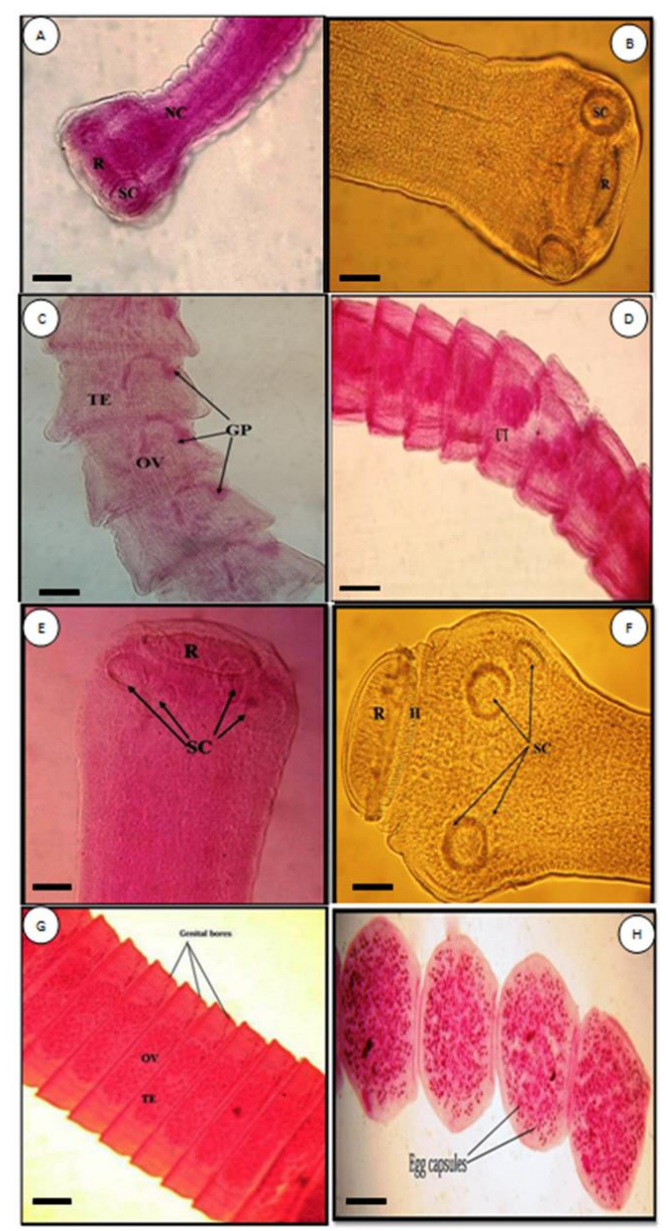

Figure (5): $R$. beveridgei: (A and B) Scolex with rostellum (R), two suckers (SC) and short neck (NC) (Acetic alum carmine), (Lactophenol. A: Scale bar $=100 \mu \mathrm{m}$. B: Scale bar $=50 \mu \mathrm{m}$. (C) Mature segments showing ovary (OV), testes (TE) and lateral genital pores (GP) (Acetic alum carmine) Scale bar $=100 \mu \mathrm{m}$. (D) Gravid segments; uterus with eggs (UT) (Acetic alum carmine) Scale bar $=100 \mu \mathrm{m}$. R. echinobothrida showing (E) Scolex with rostellum (R), four suckers (SC) and short neck (Acetic alum carmine) (Acetic alum carmine). Scale bar $=100 \mu \mathrm{m}$. (F) Rostellum (R) with two rows of hooks (H) and 4 suckers (SC) (Lactophenol). Scale bar $=100 \mu \mathrm{m}$. (G) Mature segments showing ovary (OV), testes (TE) and lateral genital pores (GP) (Acetic alum carmine) Scale bar $=100 \mu \mathrm{m}$. $(\mathrm{H})$ Gravid segments showing egg capsules (Acetic alum carmine). Scale bar $=100 \mu \mathrm{m}$. 
Intestinal Helminths Naturally Infesting The domestic Pigeon at Ismailia, Egypt.

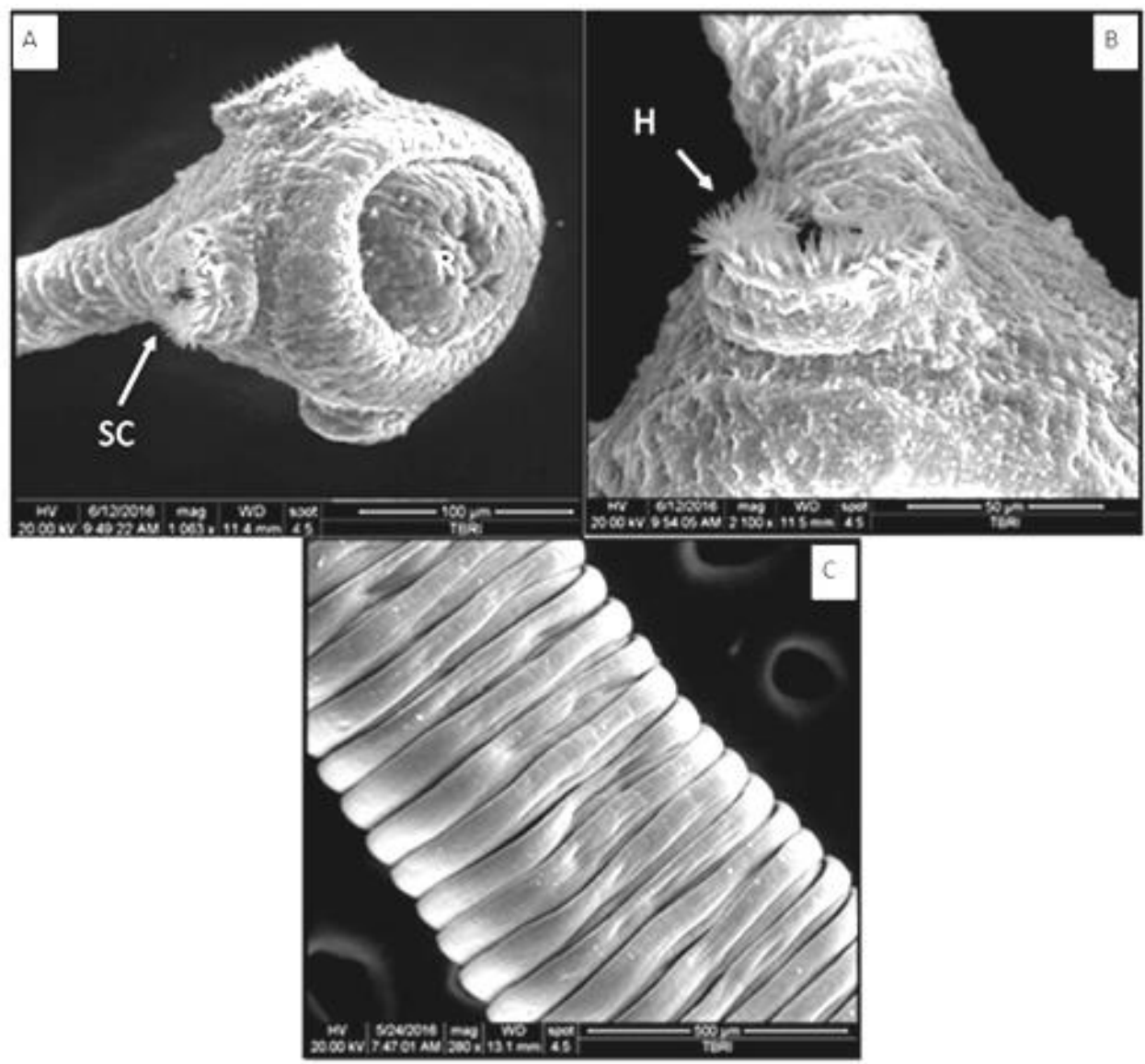

Figure (6): ESEM of $R$. beveridgei showing (A) Scolex with rostellum (R) and 3 of the 4 suckers (SC); (B) Scolex showing the hooks $(\mathrm{H})$ of one sucker; $(\mathrm{C})$ Body proglottids.
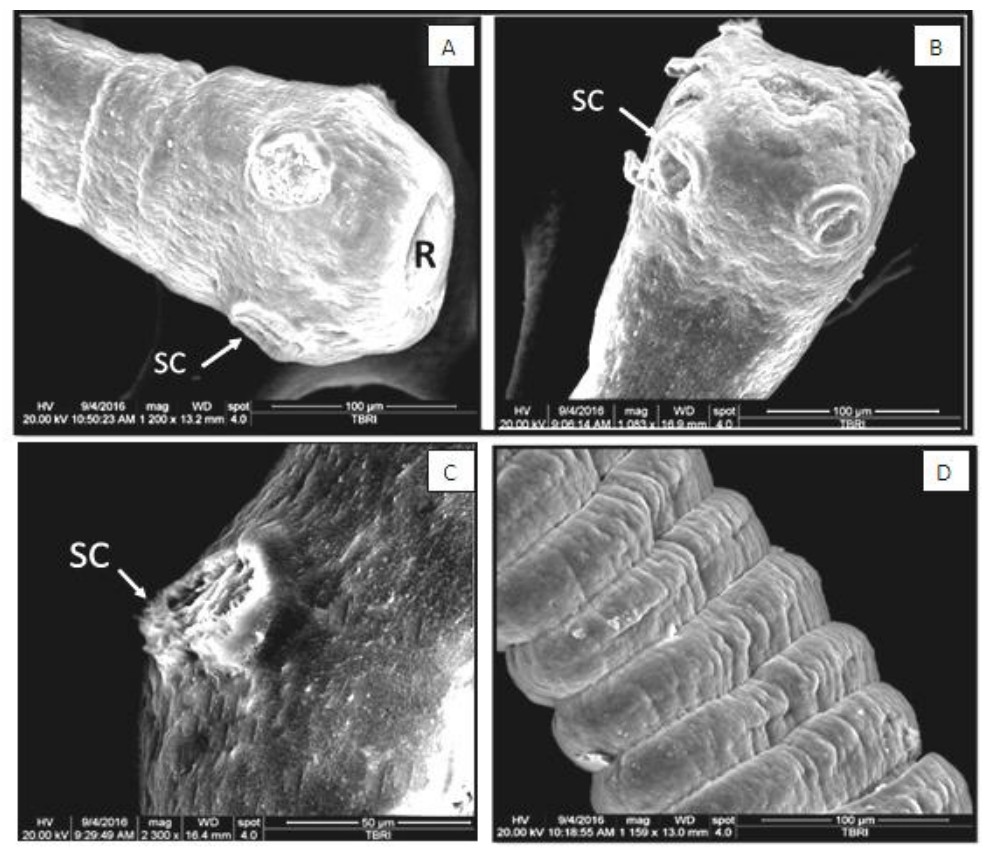

Figure (7): ESEM of $R$. echinobothrida showing (A and B) Scolex with rostellum (R) and 4 suckers (SC); (C) Scolex showing sucker (SC) with hooks; (D) Body proglottids. 


\section{Ibrahim et al.}

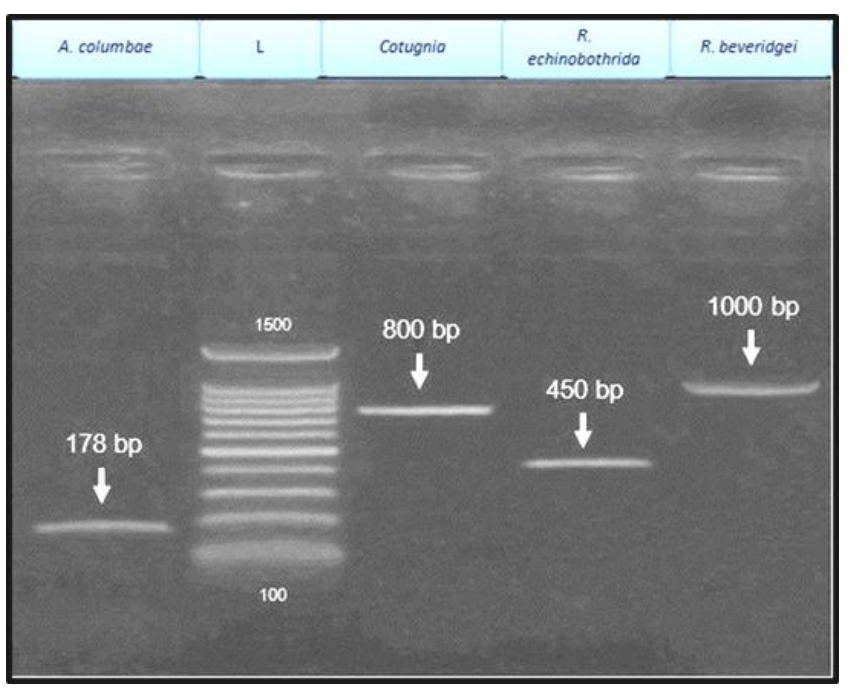

Figure (8): Electrophoretic mobility of PCR products of 18S rDNA gene for Cotugnia polycantha, ITS2 for the two Raillietina species and $\mathrm{mt}$ genome for A. columbae separated on 1.5 agarose gel. Molecular size of ladder (L) is $1500 \mathrm{bps}$.

Table (2): Edited ITS2 and 18S rRNA genes of the three recovered species (R. beveridgei, R. echinobothrida and C. Polyaca-ntha).

\begin{tabular}{|c|c|c|}
\hline Species & Gene sequence & $\begin{array}{c}\text { Accession } \\
\text { number }\end{array}$ \\
\hline $\begin{array}{l}\text { R. echinobothrida } \\
\text { ITS2 gene }\end{array}$ & $\begin{array}{l}\text { AGCGTGTGTGTGGCCTGGGGGTGCGCGTGTTGTGTGCAGGCCTCTCGGTGCTCTGGCTTCTTCCTAAGGT } \\
\text { GTGGTCGCCTCAGGTGGCGTAGAGCTAGTGGTTGTGCCATGGCTGCAGTGTATACATGTGCACGTGTGAT } \\
\text { ATATGTGCGCGTATATGTGTTGCGCTTGTGCGTGTGTGTGTGTGTACGTGTGTACGTGTGTGGGTAGCTG } \\
\text { CATTTCACAAACCTGCCTAGTGTGCTGTGTGTTTGATCTAACACTATGCGTGAGTGTGCTACTGCT } \\
\text { ACTGCTACCGCTGCTACGGGCGCCCCATGAATCTGCTTGTGGTTGGTTAGAGTCATATCTGGCTCGTGG } \\
\text { TGCGTGAGAGAGAAGAGAGAGAGAGTGGCCGCTATTTACATGTGA }\end{array}$ & MF426021 \\
\hline $\begin{array}{l}\text { R. beveridgei } \\
\text { ITS2 gene }\end{array}$ & 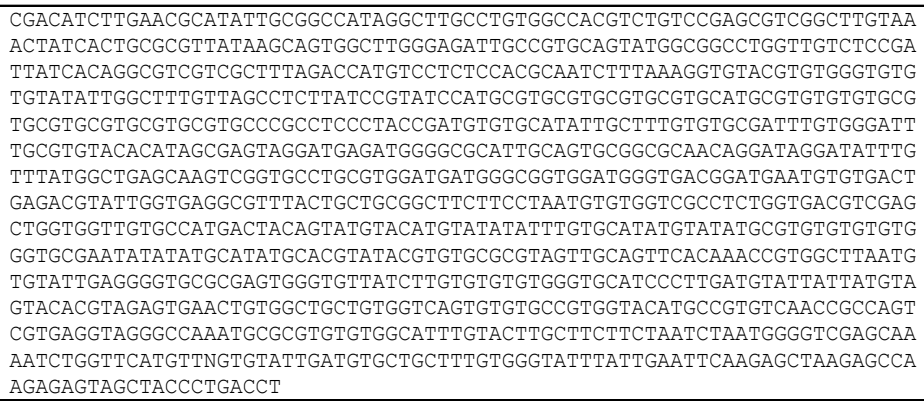 & MF426022 \\
\hline $\begin{array}{l}\text { C. polyacantha } \\
18 \mathrm{~S} \text { rRNA gene }\end{array}$ & $\begin{array}{l}\text { CACTGTTCAAGCTCTACGGCCTGCCTTGAGCGCTCCNATTTTCTCAAAGTAAACGTTCAAGTCGCCAAGG } \\
\text { ACACTCACCGAAGAGCATCCAGGACGATCTTGATCAAACAGGTGACGAGCGACGGAACGACTCCTGCTAG } \\
\text { GACGACCGTCGTCGTCGACCGCAATCCAACTACGAGCGGTTTAACCGAGCAACTTTAATATACGCTATT } \\
\text { GGAGCTGGAATTACCGCGGCTGCTGGCACCAGACTTGCCCTCCAATAGATTAGCCGAGCTTATGTACGG } \\
\text { CTCGGTCGTTCGGTAACGCTCTCATGGAGAACGTCCGTATTTTCGTCACTACCTCCCGATCCG } \\
\text { GGAGTGGGTAATTTGCGTGCCTGCTGCCTTCCTTGGATGTGGTAGCCGTTCTCAGGCTCCCTCTCCGGA } \\
\text { GTCGAACCCTGATTCTCCGTTAACCGTTGTCACCATGGTAAGCACGTAGCGTACCATCGAAAGTTGATGA } \\
\text { GCAAGTCATTTCAAAGATTCGTCGCCGTGCTGGACCGTGCGATCAGCATAGTTATTCCGATTCACCAAC } \\
\text { CTTTGGCGACGAAGGCTAAGAGCCAACGCCGATTGGTTTGTACTAATAAATGCGCTCCGACGGATT } \\
\text { AGCGCCGAAGCTTCGAGGCATGTATTAGCTCTAGAATTTCACAGTTATCCAAGTGGACATCAGTTCTTG } \\
\text { CGAACAATGGCTGTTATAATGA_CCGTTCG }\end{array}$ & MF426023 \\
\hline
\end{tabular}

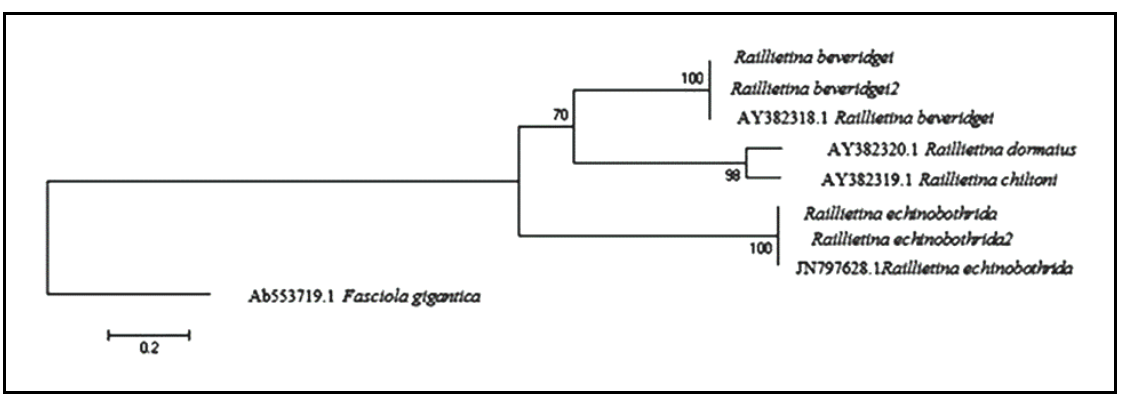

Figure (9): Maximum likelihood tree for the two samples of R. beveridgei and R. echinobothrida and other related species of genus Raillietina downloaded from GenBank. Fasciola gigantica (AB553719.1) was used as out group. 


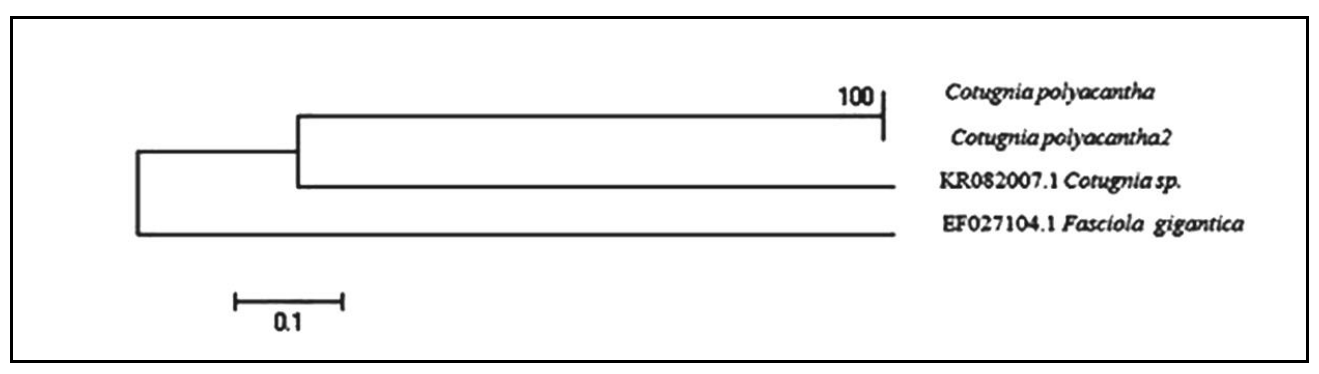

Figure (10): Maximum likelihood tree for the two samples of $C$. polyacantha and other Cotugnia downloaded from GenBank. Fasciola gigantica (EF027104) was used as outgroup.

\section{DISCUSSION}

In the present study light and environmental scanning electron microscope are used to determine the parasites surface structures since they are of great importance in the identification of the parasites on hand as mentioned by Ilie et al. (2008). A. columbae is characterized by having precloacal sucker provided with chitinized wall, spicules which are strong and equal or slightly subequal and 13 pairs of caudal papillae for male Ascaris. Tail is long, narrow and pointed, and the vulva aperture is nearly posterior to the middle of the body for females. These results are in accordance with those described by Banaja et al. (2013).

The present work showed that $C$. polyacantha are characterized by square-shaped scolex with four unarmed circular suckers and large oval retractile rostellum armed with hooks arranged in 2 rows, behind these hooks, numerous very flat spines take scale-like shape forming indentation at the base of rostellum which in an agreement with the descriptions mentioned by Bâ et al. (1995).

R. echinobothrida characterized by scolex armed with four circular suckers and oval large retractile rostellum armed with hooks arranged in 2 rows, mature segment with unilateral, single genital pores, these findings are in accordance with Ilie et al. (2008); Lalchhandama (2009); Shahin et al. (2011) and Waghmare et al. (2014). Also, $R$. beveridgei was characterized by scolex with four armed circular suckers, oval large retractile rostellum armed with hooks that arranged in 2 rows which is confirmed by the results found by O'Callaghan and Michael, (2004)

Molecular diagnosis as identification tools, among species, has been considered the most accurate and sensitive tools in recent years. Molecular markers based on DNA analysis which have been used for genetic characterization and identification of parasites especially helminths (Vilas et al., 2005). Li et al. (2011) documented that DNA sequence provided an efficient method for species level identifications under the terms DNA barcoding. Also, DNA barcoding has become one of the most important scientific trends in the last decade according to Trivedi et al. (2015).

In the present study, the identification of A. columbae is confirmed by PCR amplification and sequencing of the mt genome, the same approach was adopted by liu et al. (2013) who used the mitochondrial genes to identify the 3 different species of Ascaris: A. galli, A. columbae and Ascaridia sp. The rDNA internal transcribed spacer (ITS) sequence data have revolutionized the phylogenetic analysis as a powerful tool in resolving remarkable taxonomic issues and discriminating genera and species across a large variety of organisms, because these regions ITS spacers are more variable and more informative than other parts of the rDNA locus (Coleman, 2003). Furthermore, the ITS2 markers have also been proposed for use in species barcoding and DNA microarrays, thus increasing the detection power of closely related species (Park et al., 2007 and Engelmann et al., 2009).

Molecular analysis of gene (ITS2) is capable to differentiate between the two Raillietina species $(R$. beveridgei and $R$. echinobothridia) that was collected from the intestine of domestic pigeon. Samples of $R$. beveridgei and $R$. echinobothridia of the present study was clustered only with their closely resembling sister species in GenBank with high bootstrap $100 \%$ which supported by Berry and Gascuel (1996) who stated that high bootstrap values close to $100 \%$ mean uniform support, if the bootstrap values for a certain clade is close to $100 \%$, it means that nearly all the species of this clade have uniform characters and considered as a group.

The sequence of the data obtained in this study for $R$. beveridgei and $R$. echinobothridia ITS2 gene, was used successfully to construct a phylogenetic tree utilizing the related sequences available on the GenBank. The tree showed that our sequences were almost identical with the previous submitted sequences for the same species and highly related to $R$. dormaious and $R$. chiltoni. In turn the molecular analysis confirms the morphological identification of the samples of this study.

In the present study $18 \mathrm{~S}$ rRNA was used for the identification of $C$. polyacantha; partial sequences of the same gene were subsequently used for the evaluation of phylogenetic relationships within several orders of the Eucestoda (Mariaux, 1998). The sequence of $C$. polyacantha $18 \mathrm{~S}$ rRNA gene was used to construct a phylo-genetic tree using the related available sequences on GenBank it came out with one related sequence belong to Cotugnia sp. from India. From these results, C. polyacantha, collected from Egypt, is supposed to be the first to submit to GenBank. Molecular identification of species proved to be a very successful tool in separating morphologically similar species. Therefore, it is recommended to use molecular technique in helminths identification as the main methodological tool for accurate identification. Molecular technique was 
capable to recognize hybrid and cryptic species, the technique is more accurate with the PCR primer being very specific to the species under investigation.

\section{REFERENCES}

AL-HUSSAINI, A.H. AND E.S. DEMIAN. 1982. PRACTICAL ANIMAL BIOLOGY. VOL. II, 11TH ED. DAR Al-MAAREF. PP. 283-299.

ANWAR, A.H., S.H. RANAL, A.H. SHAH, M.N. KHAN, AND M. AKHTAR. 2000. Pathology of cestode infection in indigenous and exotic layers. Pakistan Journal of Agricultural Sciences, 37: 1-2.

BÂ, C.T., T. SENE, AND B. MARCHAND. 1995. Scanning electron microscope examination of scalelike spines on the rostellumm of five Davaineinae (Cestoda, Cyclophyllidea). Parasite (Paris, France), 2(1): 63-67.

BANAJA, A.E., A.A. ASHOUR, N.S. AWAD, M.H. AL-JODY, AND A.E. EL-TARRAS. 2013. Ultrastructural and genetic characterization of the two Ascaridia galli and A. columbae from birds in Taif, Saudi Arabia. Life Science Journal, 10(2): 17941800 .

BERRY, V. AND O. GASCUEL. 1996. On the interpretation of bootstrap trees: appropriate threshold of clade selection and induced gain. Molecular Biology and Evolution, 13(7): 999-1011.

COLEMAN, A. 2003. ITS2 is a double-edged tool for eukaryotic evolutionary comparisons. Trends in Genetics, 19: 370-375.

ENGELMANN, J.C., S. RAHMANN, M. WOLF, J. SCHULTZ, E. FRITZILAS, S. KNEITZ, T. DANDEKAR, AND T. MULLER, 2009. Modeling cross-hybridization on phylogenetic DNA microarrays increases the detection power of closely related species. Molecular Ecology Resources, 9: 83-93.

FLECK, S.L. AND A.H. MOODY. 1993. Diagnostic techniques in medical parasitology. 11th ed. Cambridge: ELBS with Tropical Health technology/Butterworth-Heinemann.

FORONDA, P., B. VALLADARES, J.A. RIVERAMEDINA, E. FIGUERUELO, N. ABREU, AND J.C. CASANOVA. 2004. Parasites of Columba livia (Aves: Columbiformes) in Tenerife (Canary Islands) and their role in the conservation biology of the laurel pigeons. Parasite, 11(3): 311-316

GHAZI, R.R., N. KHATOON, S. MANSOOR, AND F.M. BILQEES. 2002. Pulluterina karachiensis sp. n. (Cestoda: Anaplocephalidae) from the wild pigeon Columba livia Gmelin. Turkish Journal of Zoology, 26(1): 27-30.

GHOBASHY, M.A. AND A.A. TAELEB. (2015). molecular characterization of raillietina spp. ortlepp, 1938 (cestoda: cyclophyllidea: davaineidae) infecting domestic and wild birds (columba livia and Columba livia domestica). world journal of zoology, 10(2): 136-141.

KATOCH, R., R. ANISH, J.K. YADAV, S. GODARA, S. KHAJURIA, S. BORKATAKI,
AND S.S. SODHI. 2012. prevalence and impact of gastrointestinal helminthes on body weight gain in backyard chickens in subtropical and humid zone of jammu, indian journal of parasitic diseases, 36(1): 49-52.

LALCHHANDAMA, K. 2009. On the structure of raillietina echinobothrida, the tapeworm of domestic fowl. Science vision, 9 (4): 174-182.

LI, M., I.X. WANG, Y. LI, A. BRUZEL, A. L. RICHARDS, J.M. TOUNG, AND V.G. CHEUNG. 2011. Widespread RNA and DNA sequence differences in the human transcriptome. Science, 333(6038): 53-58.

LIU, G.H., R. SHAO, J.Y. LI, D.H. ZHOU, H. LI, AND X.Q. ZHU. 2013. The complete mitochondrial genomes of three parasitic nematodes of birds: a unique gene order and insights into nematode phylogeny. BMC genomics, 14(1): 414.

ILIE, M.S., G. DĂRĂBUȘ, I. OPRESCU, S. MORARIU, N. MEDERLE, A. ILIE, AND O. MEDERLE. 2008. The electrono-microscopic characterization of some helminths found in birds. Lucrari Stiintifice-Universitatea de Stiinte Agricole a Banatului Timisoara, Medicina Veterinara, 41: 402410.

MARIAUX, J. 1998. A molecular phylogeny of the Eucestoda. Journal of Parasitology, 84: 24-114.

MARQUES, S.M., R.M. QUADROS, C.J. DASILVA, AND M. BALDO. 2007. Parasites of pigeons (Columba livia) in urban areas of langes, Southern Brazil. Parasitologia Latinoamericana, 62(3-4): 183-187.

MATUR, B. AND N.M.Y. DAWAM. 2010. Gastrointestinal Helminth Parasites of Local and Exotic Chickens Slaughtered in Gwagwalada, Abuja (FCT), Nigeria. New York Science Journal, 3(5): 96-99.

O'CALLAGHAN AND G. MICHAEL. 2004. Studies on the systematics of the cestodes infecting the emu, Dromaius novaehollandiae (Latham, 1790). Ph.D, diss.

PARK, M.H., C.J. SIM, J. BAEK, G.S. MIN. 2007. Identification of genes suitable for DNA barcoding of morphologically indistinguishable Korean Halichondriidae sponges. Molecules and Cells, 23: 220227.

RAMNATH, D.B., A.K. DUTTA, B. DAS, AND V. TANDON. (2014). molecular characteri-zation of the indian poultry nodular tape-worm, raillietina echinobothrida (cestoda: cyclophyllidea: davaineidae) based on rdna internal transcribed spacer 2 region. journal of parasitic diseases, 38(1):22-6.

SARI, B., B. KARATEPE, M. KARATEPE AND M. KARA. 2008. Parasites of domestic (Columba livia domestica) and wild (Columba livia livia) pigeons in NIĞDE. Turkey Bulletin-Veterinary Institute in Pulawy, 52: 551-554.

SHAHIN, A.M., M.A. LEBDAH, S.A. ABUELKHEIR, AND M.M. ELMELIGY. 2011. Prevalence of chicken cestodiasis in Egypt. New York Science Journal, 4(9), 21-29.

SIVAJOTHI, S. AND B.S. REDDY. 2014. Lousicidal 
effect of delta methrin in domestic pigeons. Journal of Parasitic Diseases: 1-2.

SOULSBY, E.J.L. (1982). helminths, arthropods and protozoa of domesticated animals, seventhed. Bailliere tindall london. 630-637.

TADELLE, D. AND B. OGLE 2001. Village poultry production systems in central high lands of Ethiopia. Tropical Animal Health and Production, 33: 521-537.

TRIVEDI, S., A.A. ALOUFI, A.A. ANSARI, AND S.K. GHOSH. 2015. Molecular phylogeny of oysters belonging to the genus Crassostrea through DNA barcoding. Journal of Entomology and Zoology Studies, 3(1): 21-26.

VILAS, R., C.D. CRISCIONE, AND M.S. BLOUIN
2005. A comparison between mitochondrial DNA and the ribosomal internal transcribed regions in prospecting for cryptic species of platyhelminth parasites. Parasitology, 131(06): 839-846.

WAGHMARE, S., A.S. SHERKHANE, R. CHAVAN, AND V. GOMASE. 2014. Redescription on Raillietina echinobothrida (Pasquale, 1890) (Cestoda: Davaineidae) and study of conserved domain across divergent phylogenetic lineages of class cestoda. Journal of Veterinary Science and Technology, 5(3): 187.

YAMAGUTI, S.1961. Systema Helminthum. Vol. III. The Nematodes of Vertebrates. Interscience Publishers, Inc., New York, 1261 pp.

\title{
التعريف الظاهرى و الجزيئى لبعض الايدان المعوية التى تصيب الحمامة المنزلية "كولومبا ليفيا دوميستيكا"

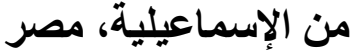

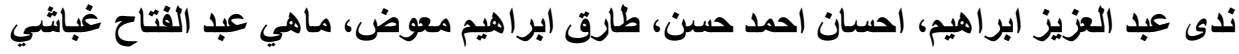

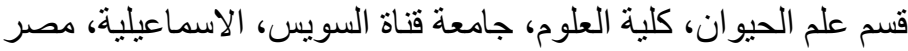 \\ الملخص العربي
}

قد حددت الدراسة الديدان الطفيلية التي تصيب الحمامة المنزلية، كولومبا ليفيا دوميستيكا(Columba livia domestica) باستخدام الأساليب التقليدية (الميكروسكوب الضوئى والمجهر البيئى الإكتروني) وكذلك طرق البيولوجيا الجزيئية. تم شراء ـ Y

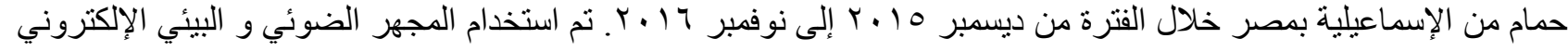
لدر اسة الخصائص الظاهرية العامة و السمات السطحية للطفيليات، وكذللك تم تأكيد هوية الديدان الطفيلية باستخدام تقنيات البيولوجيا الجزيئية من خلال الدراسة الحالية، تم تسجيل أربعة أنواع من الديدان الطفيلية؛ دودة خيطية (Ascaridia columbae) وثلاثة ديدان شريطية (Cotugnia polyacantha, and Raillietina beveridgei, Raillietina echinobothrida) وبلغت نسبة الاصابة بالديدان الطفيلية ؟.01\%. هذا وقد تم إستخدام نتائج تتابع الحمض النووي (DNA sequencing) في تعريف وتقسيم الديدان الثريطية. وجديراً بالذكر أن هذه هي المرة الأولى التى بستخدم فيها 18SrRNA C. polyacantha فى تعريف هذا النوع من الديدان الطفيلية فى مصر وسوف يتم تسجيلها فى بنك الجينات. أيضا أظهر تفاعل ال PCR نتائج إيجابية فى تعريف الدودة الخيطية A. columba، ولهذا فمن الافضل استخدام التقنية الجزيئية في تحديد الديدان الطفيلية وخاصة في الأنواع ذات 